\title{
Analysis of Desires of the Main Character in the Short Story "Ein Tisch ist ein Tisch" by Peter Bichsel: A Study of Deleuze and Guattari's Schizoanalysis
}

\author{
M. Kharis', Rosyidah², Sawitri Retnantiti \\ 1,2,3 Universitas Negeri Malang, Malang, Indonesia \\ 1Email:m.kharis.fs@um.ac.id
}

Submitted: 20/12/2019

Revised: 31/12/2020

Accepted: 23/01/2020

E-ISSN : 2579-4574

P-ISSN : 2549-7359

\begin{abstract}
This study aims to describe the desires of the main character 'der Mann' in the short story by Peter Bichsel using Deleuze and Guattari's Schizoanalysis theory. This was a qualitative study with a descriptive approach. The research data were comprised of words, phrases, and sentences. The collected data were subsequently categorized into types of desires. Data were analyzed using reading and recording techniques and described based on the proportion of desires. The results of the analysis showed that the main character receives constant pressures from society, leading to the emergence of paranoid desire, a desire that is formed due to the pressure of particular systems or social codes outside of the main character. This desire is schizophrenic at the individual level. In the short story, this desire is manifested through the creation of a new language by 'der Mann'. In the end, the main character 'der Mann' can use new vocabulary at the levels of phrases and sentences, but unable to influence other language users. As a result, his newly self-created language is unacceptable in society. However, the schizophrenic desire at the individual level has the potential to destruct social formation.
\end{abstract}

Keywords: Schizoanalysis, Schizophrenic Desire, Ein Tisch ist ein Tisch

https://ojs.unm.ac.id/eralingua

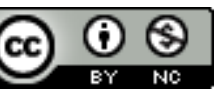

This work is licensed under a Creative Commons Attribution-NonCommercial 4.0 International License. 


\section{INTRODUCTION}

Psychoanalysts believe that desires are always negatively dogmatic. Desires in terms of psychoanalytic philosophy tend to be destructive and harmful; thus, formalization by Oedipus is necessary for the categorization of desires (Murti, 2017). Psychoanalysts view that activities and movements of desires are subject to social codes; for instance, femininity and masculinity, tradition, beliefs, and other forms inherent in an individual or a society. Freud reveals that humans emasculate desires to be allowed to be discussed in social matters (Manik, 2015). Social codes are integrated into the practice of life; thus, an agreement is made about proper and improper things as well as appropriate and inappropriate things. This, in psychoanalysis, called the superego.

In reality, social codes limit the desire to act. Both individuals and community groups are not allowed to be anti-mainstream because deviations from the rules of social codes are considered threatening and incompatible with traditions. Desires are creative energy since desires have the potential to create a new reality (Murti, 2016). Meanwhile, Oedipus is an obstacle (Deleuze \& Felix, 2000). In other words, desires have the function to unravel the nodes of social codes that lead to the restriction of the society's submission to the territory.

Deleuze dan Guattari argue that culture develops because an individual with the desire to move refuses to obey and defer to social codes. Thus, desires should not be restricted by social codes. The omission of desire to have the freedom of movement is called deterritorialization, the movement to self-detach from the power that suppresses an individual and the territory claimed by psychoanalysts (Murti, 2017). This is what Deleuze and Guattari mean by schizoanalysis, which is the opposite of psychoanalysis. The word schizo has a metaphorical meaning, which refers to a person who does not want to be ruled by the entire structure of social codes. In this regard, schizophrenic does not refer to a clinical condition of mental illness, but the tendency of potential for permanent transformation and revolution (Žukauskaitè, 2018)

Some studies on schizoanalysis have been conducted. Bakir interpreted the theories by Deleuze and Guattari about the concepts of Desire Machine, Territorialization-Deterritorializatiion-Reterritorialization, and Rhizome and Tree, as well as the alternative applications in contemporary architecture in the form of images and ideas with the architecture style of deconstructivism (Bakir et al., 2015). Bakir applied the theory by Deleuze and Guattari in architecture in his research, while Gilbert adapted Deleuze and Guattari's critical ideas to music. Gilbert argues that the adaptation of the critical ideas of Deleuze and Guattari to music allows it to provide a single environment for the actualization and reflection about the ontology of change and the effect of 'being' (Kielian-Gilbert, 2016). A study by Suryosumunar showed that consumerist society is formed in the area of deterritorialization disseminated by the media. This condition is contrary to the principles of immanence and liable to hamper rather than improve life (Suryosumunar, 2019). In addition, a study by Purwadi indicated that capitalist products have turned society into a powerful engine of desire because people have 
freedom of desire (Purwadi, 2017). Besides, Pialiang said that the current culture is developing toward hyperreality, a culture that has "transcended" the boundaries of its own identity, form, principles, and nature. This is the mixture of cultures from various heterogeneous sources, which contradictorily creates a schizophrenic culture (Piliang, 2009).

The aforementioned studies suggest that schizoanalysis holds a belief that in architectural, music, commercial, cultural and other areas of life, humans want to have the freedom to move, to will and to leave from social codes to discover new and different things.

Schizo has his own system of co-ordinates for situating himself at his disposal, because, first of all, he has at his disposal his very own recording code, which does not coincide with the social code, or coincides with it only in order to parody it. The code of delirium or of desire proves to have an extraordinary fluidity. It might be said that the schizophrenic passes from one code to the other, that he deliberately scrambles all the codes (Deleuze \& Felix, 2000).

The explanation above suggests that Schizo has his own code system, a system that is different from the existing social codes. Even if such a system has existed, this self-made system is only for imitation with messages of parody. A concrete example of a self-made code system is slang derived from the English words used among teenagers. Slangs are readily accepted and commonly used by teenagers. Unexpectedly, slangs can "ruin" standard grammar rules. This situation can also happen to other social codes in social life. It can be concluded that the person with schizophrenia is able to penetrate from one code to another code and to intentionally abuse the established codes. This situation is understandable since humans are principally desire engines connected to other desire engines (Nugroho, 2017). Desire is the force of life as it becomes the source of creativity used to deal with various problems (Haryatmoko, 2015).

Both individual and society can turn social codes into objects in literary works. A literature work generally portrays human lives and the environment. Literature is created on the basis of humans' impetus to express their existence and imagination into which the author's emotional feelings are poured. The way existence and imagination are poured into literary work distinguishes not only between one author and another author but also between one literary work and another literary work. Literary works describe life, and life is comprised of social facts and cultures.

The presence of literary works is inextricably linked with the author's identity as the creation process of literary work usually reflects the author's social life. The author often incorporates his or her experiences into work with some additions of fictional elements. Consequently, literary works are often regarded as a portrait of the life and a product of human creativity.

The current study examines the German short story by Peter Bichsel as its material object. A short story is a literary work that emanates social codes. One of Peter Bichsel's short stories is called "Ein Tisch ist ein Tisch," which literally means " $a$ table is a table" (Bichsel, 1995). Although this short story is frequently used to facilitate literature learning in German elementary schools (Conard, 1981), few 
studies on this short story have been done. Based on the search results on scholar.google.com accessed on January 21, 2020 using the keyword Ein Tisch ist ein Tisch, 266 titles and articles were found as well as six citations, three journal articles (Conard, 1981; Krause, 2012; Prang, 2010) and one undergraduate thesis (Pamungkas, 2010).

The short story tells a significant conflict in the character 'der Mann' who wants changes in German. He protests and opposes the agreement about the arbitration of a language. Through this main character, Peter Bichsel gently narrates the character's self-conflict. Besides, social codes and the main character's desire are clearly displayed. Desires generate constant pressures afflicting the main character. Desire in schizoanalysis can be manifested into paranoid and schizophrenic desires. Paranoid desire is shaped by particular systems outside the main character. In contrast, schizophrenic desire at the individual level potentially destructs social formation and, at a higher level, potentially causes comprehensive transformation by ruining the system (Muhsyanur, 2018). Deleuze analogizes a theory to a toolbox, which enables the concept of philosophy to create possibilities for various fields of research (Colombat, 1991).

The selection of the short story was based on Conrad's statement indicating that the short story is most appropriately used to introduce German literature. Conrad's study revealed that glossaries help students comprehend the story with ease and feel its seriousness and depth (Conard, 1981). Prang also conducted a study on this short story and concluded that semiotic discourse functions as a source of inspiration that leads beyond academic responses to the creative compositions of fictional texts (Prang, 2010).

If the study by Conrad focused on the short story Ein Tisch ist ein Tisch as the material object in learning literature for elementary students and the study by Prang on the semiotic aspect of the short story, the current study puts the focus on Deleuze and Guattari's desire theory of schizoanalysis to show how the main character in the short story fights for his desire. Based on the background explained previously, this study aims to describe the desire of the main character in the short story Ein Tisch ist ein Tisch by Peter Bichsel using the schizoanalysis theory by Deleuze dan Guattari.

\section{RESEARCH METHOD}

This study employed a descriptive approach. Data were obtained from the short story Ein Tisch ist ein Tisch written in German by Peter Bichsel and its translation in English by Davis (Davis, 2017), comprised of words, phrases, and sentences selected concerning the focus of the current research. Data were collected through reading and recording techniques, involving repeated readings in order to gain a comprehensive understanding of the data. Data were subsequently categorized into several types. Although Deleuze and Guattari's schizoanalysis theory is not a research method, it is integrated into the research method (Biddle, 2010) and becomes part of the research. Data were analyzed to find desires opposed to social systems (Ringrose, 2011) using objective hermeneutics technique and presented in a descriptive method. The analysis results were validated by 
triangulations and Forum Group Discussion (FGD) with colleagues to obtain accurate interpretations regarding the data found.

\section{RESULT AND DISCUSSION}

Prior to the discussion of the results, the following is the synopsis of the short story Ein Tisch ist ein Tisch. This short story talks about a lonely old man who goes through the days with the same routines: having walked in the morning and afternoon, greeting neighbors and sitting in his apartment. Every time he returns to his apartment, everything remains the same. Afterward, he decides to make changes. He swaps the names of objects in his apartment: "table" is swapped for "carpet"; "bed" is swapped for "photo"; etc. He also changes and swaps the meaning of words from all word classes. He becomes increasingly obsessed with the new language he has modified for himself. This new language brings him joy. Moreover, he compiles a dictionary for his new words. The old man learns the language persistently. He gradually memorizes his new language; thus, people often laugh when he is talking. They think that he sounds very funny. This, in fact, is not a funny story. On the contrary, this is a sad story as he eventually cannot communicate with others. This old man cannot use his old language anymore. He is aware of the situation but increasingly immersed in his world. He can no longer talk with other people.

Through the reading and recording technique, the following are the data classified as desires and the explanation.

\section{Data 1:}

„Es muss sich etwas ändern. “ Und er hörte den Wecker nicht mehr.

(Translation: 'It must change. It must change!' And he could no longer hear the alarm clock).

The main character, 'der Mann", takes a walk every morning and afternoon around the neighborhood and greets neighbours. When the night comes, he sits by the table. There is no difference between workdays and holidays, and so on until those days make him feel bored with the routine. He does not want to have a routine about which the society is dogmatic that morning and afternoon are the perfect time for a walk. Die Trendanalyse zeigt, dass heute deutlich mehr Ältere für Aktivitäten aus dem Haus gehen als noch vor zehn oder zwanzig Jahren means that the trend analysis shows more elderly people conduct activities outside the house nowadays than those did 10 or 20 years ago (Generali Deutschland AG, 2017). As an elderly person himself, 'der Mann' should also do the same. However, he desires changes in what he does in the afternoon. Thus, he seems to possess schizoanalysis with schizophrenic desire at the individual level.

\section{Data 2:}

Hie und da träumte er schon in der neuen Sprache, und dann übersetzte er die Lieder aus seiner Schulzeit in seine Sprache, und er sang sie leise vor sich hin. 
(Translation: From time to time, he would dream in the new language, and then he translated the songs from his schooldays into his language, and he sang them softly to himself).

One of the changes 'der Mann' does is changing language symbols. Translating songs into a new language indicates a schizophrenic desire at the individual level. Destructing a standard language has been studied by Zakiah. The results showed that slangs and new terms are found in the forms of abbreviations, acronyms, combinations of abbreviations and acronym and separation of words from Indonesian, English and combinations of Indonesian and English (Zakiah, 2018). This desire potentially destructs the standard grammatical rules of a language that has been created by society. The destruction process of meanings of language symbols is continuously done as shown in Data (3) below.

\section{Data 3:}

Der Mann fand das lustig, und er übte den ganzen Tag und prägte sich die neuen Wörter ein. Jetzt wurde alles umbenannt.

(Translation: The man found this fun, and he practised the whole day and memorised the new words. Now everything was renamed).

The next paragraph tells that 'der Mann' keeps doing destruction on the grammatical rules of the standard language. He changes the meanings of words from all word classes. Now he has left his boring daily routine. In fact, he composes a dictionary and memorizes new words. Data (3) shows that 'der Mann' has schizoanalysis with the schizophrenic desire at the individual level that potentially ruins social formation. In addition to the study by Zakiah, Hidayah found how the use of slang among students diminishes the existence of the standard language as the national language (Hidayah, 2020).

\section{Data 4:}

Dann lernte er für alle Dinge die neuen Bezeichnungen und verga $\beta$ dabei mehr und mehr die richtigen.

(Translation: But soon translating was also hard for him, he had almost forgotten his old language, and he had to search for the right words in his blue notebooks).

The main character 'der Mann' is still trying to follow his desire to change grammar rules. Data (4) illustrates that he has schizoanalysis with the schizophrenic desire. If the studies by Zakiah and Hidayah showed that new words are quickly accepted by teenagers, 'der Mann' is still at the composition process. However, 'der Mann' ignores the fact that the development and the acceptance of new words and terms of a language highly depend on how successful new words and phrases in that language are created (Assapari, 2014).

\section{Data 5:}

Er hatte jetzt eine neue Sprache, die ihm ganz allein gehörte. 
(Translation: He had a new language that belonged only to him).

Data (5) signifies that he has fully met his schizophrenic desire at the individual level by destroying his mother language and making a new language. Despite being destructive, der Mann's motivation can be used as an example in vocabulary learning as illustrated in the diagram below.

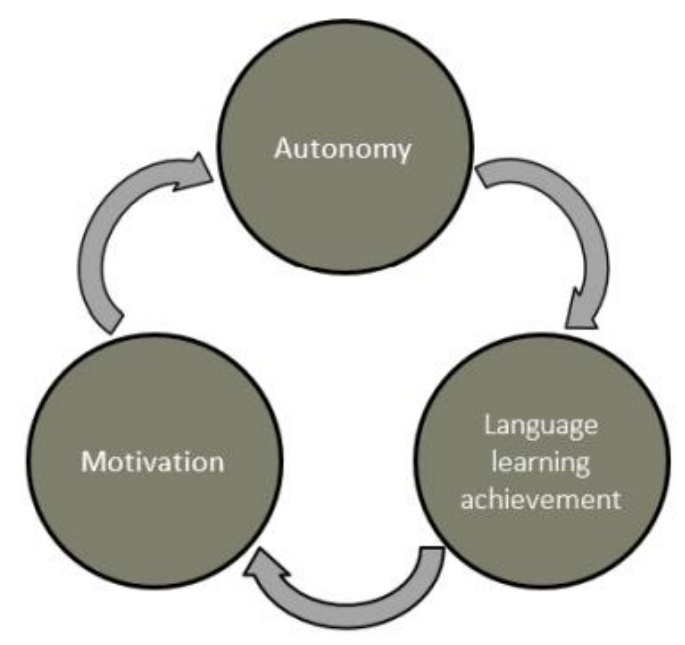

Figure 1: Cycle of success in learning a foreign language (Bravo et al., 2017)

Through perseverance in learning and strong motivation, 'der Mann' can master a new language. Memorizing words and then combining them in sentences reflect the actual process of learning a new language in which language mastery begins with vocabulary learning. This is in line with the study by Bravo, who found that learners find lexis more important than syntax when it comes to choosing activities to master the new language (Bravo et al., 2017).

\section{Data 6:}

Er musste lachen, weil er all das nicht verstand.

(Translation: He had to laugh because he did not understand all that).

He often laughs at how people talk. For him people sound funny when talking because the meanings of other people's sentence structures are different from the sentences structures in his new language. This obviously contradicts vocabulary development proposed by Stoller and Grab that vocabulary development can be performed by recycling vocabulary in meaningful contexts (Stoller \& Grabe, 2018). The character 'der Mann' performs vocabulary development by recycling existing words, but ignores the meanings of vocabulary he has created, resulting in unacceptable words.

\section{Data 7:}

Aber eine lustige Geschichte ist das nicht. Sie hat traurig angefangen und hört traurig auf. Der alte Mann im grauen Mantel konnte die Leute nicht mehr verstehen, das war nicht so schlimm. 
(Translation: But this is not a funny story. It began sadly, and it ends sadly. The old man in the grey coat could no longer understand people, that wasn't so bad. Much worse was that they could no longer understand him).

He does not expect that society cannot accept his new vocabulary. Data (7) is the anti-climax of the schizophrenic desire of the main character in this short story. He fails to change the grammar rules of a language. He forgets that language is a mutual agreement in communication. An individual cannot modify the arbitrary of a language only based on individual desire. Besides, the application of concept maps on definitions and semantic maps as well as word chains, can foster users' vocabulary retention (Stoller \& Grabe, 2018). As a result, language transformation can only be done by the society in general and agreed upon universally. If an individual desire to make changes to a language, he or she must do it together with the members of society so that the changes can be accepted by society. Otherwise, data (8) can serve as evidence that the main character 'der Mann' fails to conquer schizophrenic desire in him.

\section{Data 8:}

Viel schlimmer war, sie konnten ihn nicht mehr verstehen. Und deshalb sagte er nichts mehr. Er schwieg, sprach nur noch mit sich selbst, grüßte nicht einmal mehr.

(Translation: Much worse was that they could no longer understand him. And therefore he said nothing more. He was silent, spoke only to himself, did not even greet them).

Human desires are formed in such a way in order to correspond to the Oedipus system as if it can fulfill all human desires. This, however, is not always the case. When the Oedipus system can no longer satisfy the urges, ideas, codes, and symbols that desires require, the limitations of the Oedipus system are found (Nugroho, 2017). The main character, 'der Mann, ' feels boredom under the influence of the Oedipus system and wants to rebel out of it. With great creativity, he managed to satisfy his schizophrenic desires. The dictionary composition for new words is the manifestation of his schizophrenic desires. The main character 'der Mann' disregards the three-dimensional requirements of vocabulary development, namely partial to precise knowledge, depth of knowledge, and receptive to productive use-ability (Henriksen, 1999). Indeed, the main character succeeds in realizing his schizophrenic desires at the individual level but fails to do so at a higher level. He is able to use new vocabulary at the levels of phrases and sentences but is unable to influence potential users of his new language. As a consequence, it is unacceptable in society.

\section{CONCLUSION}

The main character 'der Mann' is shown to have schizoanalysis, which is understood as a personality that obeys social codes. This is called a deterritorialization. Thus, he favors the freedom from the limiting power and finds pleasure in free movement. The main character 'der Mann' in the short story by 
Peter Bichsel has schizophrenic desires that put constant pressures on him. The desires at the individual level potentially destruct social formation even though he eventually fails to ruin it and cannot make changes to the language system.

\section{REFERENCES}

Assapari, M. M. (2014). Eksistensi Bahasa Indonesia sebagai Bahasa Nasional dan Perkembangannya di Era Clobalisasi. PRASI, 9(18). https://doi.org/10.23887/prasi.vgi18.8943

Bakir, S., Pandiangan, M. L., Anggita, G., \& Alexander, R. (2015). Interpretasi Teori Deleuze dan Guattari dalam Arsitektur. ATRIUM - Jurnal Arsitektur, 1(2). http://library.ukdw.ac.id/atrium/index.php/atrium/article/view/13

Bichsel, P. (1995). Ein Tisch ist ein Tisch: Eine Geschichte. Suhrkamp.

Biddle, E. (2010). Schizoanalysis and collaborative critical research. Aporia, 2(3). https://doi.org/10.18192/aporia.v2i3.2984

Bravo, J. C., Intriago, E. A., Holguín, J. V., Garzon, G. M., \& Arcia, L. O. (2017). Motivation and Autonomy in Learning English as Foreign Language: A Case Study of Ecuadorian College Students. English Language Teaching, 10(2), 100113.

Colombat, A. P. (1991). A Thousand Trails to Work with Deleuze on JSTOR. The Johns Hopkins University Press, SubStance. Vol. 20, No. 3, Issue 66: Special Issue: Deleuze \& Guattari (1991), pp. 10-23 (14 pages). https://doi.org/DOI: $10.2307 / 3685176$

Conard, R. C. (1981). Teaching Peter Bichsel's "Ein Tisch ist ein Tisch" in First-Year German Classes. Die Unterrichtspraxis / Teaching German, 14(2), 286. https://doi.org/10.2307/3530567

Davis, L. (2017, March). A Table is a Table-The White Review. http://www.thewhitereview.org/fiction/a-table-is-a-table/

Deleuze, G., \& Felix, G. (2000). Anti-Oedipus, Capitalism and Schizoprenia (Translated by Robert Hurley, Mark Seem, and Helen R. Lane). Minnepolis.

Generali Deutschland AG. (2017). Alltag und digitale Medien. In Generali Deutschland AG (Ed.), Generali Altersstudie 2017: Wie ältere Menschen in Deutschland denken und leben (pp. 89-122). Springer. https://doi.org/10.1007/978-3-66250395-9_4

Haryatmoko. (2015). Gilles Deleuze (1): Filsafat Hasrat Menolak Tabu. Jurnalisme Seribu Mata Basis Menembus Fakta, No 1 dan 2(Tahun ke-64).

Henriksen, B. (1999). Three Dimensions of Vocabulary Development. Studies in Second Language Acquisition, 21(2), 303-317. https://doi.org/10.1017/S0272263199002089

Hidayah, S. N. (2020). Pengaruh Bahasa Gaul terhadap Eksistensi Bahasa Indonesia pada Siswa Kelas $X$ MAN 1 Karanganyar [Preprint]. INA-Rxiv. https://doi.org/10.31227/osf.io/s5t7a

Kielian-Gilbert, M. (2016, April 1). Music and the Difference in Becoming. Sounding the Virtual: Gilles Deleuze and the Theory and Philosophy of Music. https://doi.org/10.4324/9781315609966-15

Krause, S. (2012). Literatur mal anders-Peters Bichsels" Ein Tisch ist ein Tisch". 
Manik, R. A. (2015). Hasrat Nano Riantiarno Dalam Cermin Merah:Kajian Psikoanalisis Lacanian (Nano Riatno's Desire in "Cermin Merah": Lacanian Psychoanalysis Study). Jurnal K A N D A I, Volume 11 No. 2, November 2015.

Muhsyanur. (2018). Hasrat Kepribadian Tokoh Utama dalam Novel "Memburu Matahari” Karya Nadjib Kartapati Z. Jurnal Belajar Bahasa, olume 3, No. 2, September, $189-196$.

Murti, G. H. (2016, February 7). Gilles Deleuze: Meneropong Karya Minor Kafka. http://www.brikolase.com/2016/02/07/deleuze-meneropong-karya-minorkafkal

Murti, G. H. (2017). Mesin hasrat dan kreativitas budaya tanpa batas: Perpusda Jember, Sekolah Kritik Budaya Angkatan I, 10.

Nugroho, W. B. (2017). Mimi Peri dan Revolusi Hasrat: Tinjauan Skizoanalisis Deleuze dan Guattari. Sanglah Institute. https://www.sanglahinstitute.org/2017/12/mimi-peri-dan-revolusi-hasrat-tinjauan.html

Pamungkas, B. B. P. (2010). Masalah komunikasi pada empat karya Peter Bichsel: San Salvador, das Kartenspiel, der Milchmann, dan Ein Tisch ist ein Tisch.

Piliang, Y. A. (2009). Retakan-retakan Kebudayaan: Antara Keterbatasan dan Ketakberhinggaan. MELINTAS, 25(1), 75-92.

Prang, C. (2010). Semiomimesis: The influence of semiotics on the creation of literary texts Peter Bichsel's Ein Tisch ist ein Tisch and Joseph Roth's Hotel Savoy. Semiotica, Volume 2010, Issue 182, Pages 375-396, ISSN (Online) 16133692, ISSN (Print) 0037-1998,. https://doi.org/10.1515/semi.2010.064.

Purwadi, Y. S. (2017). Kapitalisme Mutakhir: Mesin Hasrat yang Tak Terkalahkan. Extension Course Filsafat

http://journal.unpar.ac.id/index.php/ECF/article/viewFile/2890/2493

Ringrose, J. (2011). Beyond Discourse? Using Deleuze and Guattari's schizoanalysis to explore affective assemblages, heterosexually striated space, and lines of flight online and at school. Educational Philosophy and Theory, 43(6), 598618. https://doi.org/10.1111/j.1469-5812.2009.00601.x

Stoller, F. L., \& Grabe, W. (2018). Innovative Strategies for Vocabulary Development. In The TESOL Encyclopedia of English Language Teaching (pp. 1-8). American Cancer Society. https://doi.org/10.1002/9781118784235.eelt0750

Suryosumunar, J. A. Z. (2019). Perspektif Gilles Deleuze terhadap Proses Imitasi dalam Masyarakat Konsumeris di Era Revolusi Industri 4.0. Waskita: Jurnal Pendidikan Nilai dan Pembangunan Karakter, 3(2), 43-58. https://doi.org/10.21776/ub.waskita.2019.003.02.4

Zakiah, K. (2018). Abreviasi Bahasa Gaul Remaja. Kelasa, 13(1), 1-16.

Žukauskaitè, A. (2018, May 1). The schizoanalysis of Gilles Deleuze and Félix Guattari, or the political between schizophrenia and paranoia. Nationalism and the Body Politic. https://doi.org/10.4324/9780429477522-12. 